\title{
Role of Environmentalism in the Development of Green Purchase Intentions: A Moderating Role of Green Product Knowledge
}

\author{
Mirza Ashfaq Ahmed ${ }^{1 *}$, Aleena Arshad ${ }^{1}$, Muhammad Anwar ul Haq ${ }^{1}$, Bushra Akram² \\ ${ }^{1}$ Department of Management Sciences, University of Gujrat, Gujrat 50700, Pakistan \\ ${ }^{2}$ Department of Psychology, University of Gujrat, Gujrat 50700, Pakistan
}

Corresponding Author Email: ashfaq.ahmed@uog.edu.pk

https://doi.org/10.18280/ijsdp.150714

Received: 18 July 2020

Accepted: 2 October 2020

\section{Keywords:}

environmentalism, green products, green value, green product knowledge, green purchase intentions

\begin{abstract}
Environmentalism has become not only a significant policy issue but also a crucial topic in marketing research. Environmental consciousness is now considered as a fundamental requirement to prevent further damage to the environment. Efforts have been made to improve the consumers understanding about the environmental consequences of their consumption patterns. This study develops a conceptual model of green purchase behaviour to determine the effects of environmentalism, advertisement message credibility and green perceived value on the consumers' green purchase intentions with green product knowledge as a moderator. The convenience sampling technique with cross-sectional research design was used to select the sample. Data were collected using survey, and a total of 368 valid questionnaires were used for further analysis. The results from the structural analysis using Smart-PLS depict that environmentalism significantly influences the ad message credibility and green perceived value, and these constructs significantly affect the green purchase intentions. Furthermore, the green product knowledge moderates the relationship between environmentalism, ad message credibility and green perceived value. Overall, the findings of this study extend the theoretical basis of green purchase intentions by empirically testing the proposed model and provides the limitations and further research directions.
\end{abstract}

\section{INTRODUCTION}

Healthy ecosystems are gaining the pivotal importance across the world due to their strong effects on human wellbeing and public health [1]. However, human activities from last many decades have severely destroyed the balance of ecosystems [2]. Natural environment is substantially affected by the irresponsible behaviours of human. The continuity of these activities and behaviours sooner or later generates unhealthy living conditions, sudden environmental shifts and depletion of scarce recourses. World has now recognized that the environmental problems must be treated as the most pressing issue and there is a need to take responsible and proactive measures to improve the environmental conditions [3]. Many countries have now placed the environmental concerns at their top priorities and taking serious actions to avoid the further deterioration of their environment. The most prominent actions include educating their residents, increasing awareness campaigns, engaging society, revaluating their environmental policies and encouraging sustainable production and consumptions [4].

Human consumption is regarded as one of the main sources responsible for climate shifts, waste material generation and depletion of scarce resources. Therefore, sustainable consumption is gaining much-needed importance to increase the consumption of products having a minimum impact on the environment quality [5]. Usage of such environment friendly or eco-friendly products also known as green products can substantially contribute in maintaining healthy environment
Because, production and consumption of green products strive to impose less harm to the environment by conservation natural resources, and reducing the pollution. Therefore, preferences must be given to green products to achieve the sustainable consumption [6]. Consumers have to play a fundamental role to support sustainable consumption by adopting green consumption behaviours. Similarly, the marketers have to promote the green products through redefining their promotional strategies. Many companies are actively engaged promoting green product consumption behaviour through their advertisements by considering it as their social responsibilities [7]. However, despite these efforts, consumers even do not purchase or not purchasing green products on a regular basis as expected. These are the reasons that market share of green is still less than $4 \%$ worldwide [8].

Special efforts from all stakeholders are required to increase the market share of green products by raising environmental consciousness and social responsiveness. This could be achieved through better understanding the consumers, attitudes and convincing them to prioritize green products while making purchase decisions. This increased environmental conscientiousness ultimately forces the producers to produce environment-friendly products to align them with the requirements of green customers and environment [9]. However, lack of green product knowledge is considered as the main barrier toward adoption of green product behaviour [10]. On the other side, green product knowledge is regarded as the main motivator of green consumption [6]. Therefore, level of green product knowledge 
creates the major difference toward greed purchase behaviour. Similarly, environmentally conscientious consumers strongly perceive green products related advertisements credible and reality based without any doubt as compared to consumer having no or less environmental conscientiousness [11]. Furthermore, environmental cautious customers perceive more green purchase values in green products rather than making purchase decisions on the basis of economic values of products $[3,12,13]$.

The main objective of this study is to examine the role of determinants, environmentalism, ad message credibility, green perceived value and green product knowledge, in the development of green purchase intentions. Therefore, a multifactor conceptual model is proposed to evaluate the effects of environmentalism on ad message credibility and their subsequent contribution in green purchase intentions. Similarly, to evaluate the effects of environmentalism on green perceived value and their subsequent contribution in green purchase intentions. Furthermore, the green environmental knowledge is proposed as a moderator between two paths, first, environmentalism and ad message credibility constructs and second, environmentalism and green perceived values constructs. This empirical study is based on data gathered from relatively young respondents belonging to environmentally cautions generation by employing a self-administered questionnaire based survey. The model is conceptualized on the basis of a comprehensive literature review following contributions of previous landmark studies from the relevant domain. The model is tested with SmartPLS version 3.9, and research results are presentenced in the tabular form of an interpretation and discussion followed by conclusion, limitations and further research recommendations. This study provides insight for marketing managers or practitioners into the process to influence the purchase and consumption of environment-friendly products. This study also theoretically contributes to the field of green purchase behaviours by empirically analysing the relationships among environmentalism, ad message credibility, green perceived values and green purchase intentions.

\section{LITERATURE REIVEW AND HYPOTHESES DEVELOPMENT}

\subsection{Environmentalism}

The term environmentalism has been defined in a number of ways e.g. 'the advocacy of the preservation, restoration, or improvement of the natural environment' (Merriam-Webster), an environmental activity aimed to conserve natural environment [14], protecting the environment from degradation caused by human activities [14], a sustainable development [15], environmental values and concerns [3], consumption of environment-friendly products [16]. Further, the environmentalism concept is also defined as the rise of concerns and awareness among the society towards environment and the shift in perspective or thinking of the consumers in favor of environment [17]. More recently, the definitions of the environmentalism are further extended as a tendency to act with pro-environmental intentions and proenvironment behavior to benefits the natural environment, enhance environment quality or cause minimum harm to the environment [18]. Environmentalism is a form of environmental consciousness or conservation; consciousness in the world confronted by global environment changes, the collapse of ecosystem and loss of biodiversity due to human presence and influence [19]. These diverse natures of definitions have a common underlying theme to conserve the components of natural environment with the help of consumers. Environmental conditions are largely dependent on the environment friendly consumption behavior of the consumers. Sustainable and pro-environment consumption behaviors directly contribute in developing and maintaining the healthy eco-system. Therefore, environmentalism is regarded as the foremost essential for the objective of gaining a better world [20]. However, the consumers have powerful influence to gain this objective by favorably contributing to conserving the natural environment. Environmental attitude and environment behavior of the consumers have significant contribution in saving the natural environment [21]. Environmental attitude relates to an awareness of environmental issues and a commitment to preservation. Environment behavior means actions taken on the basis of environmental attitude to positively influence the behavior and the choice of environmental activities [22]. With the sudden rise in production and consumption pattern of the world, the environment and its components are under a constant threat to get polluted due to irresponsible human activities. Imbalance in the natural environment has serious consequences. Therefore, attempts must be made by all the stakeholders to save the natural environment, because, unhealthy environment is responsible for unpleasant living conditions for human beings [23]. Unfortunately, people fail to take concrete measures and to adopt socially and environmentally positive behaviours. This is the reason that environmentalism becomes the most pressing problem of the recent times [3]. Therefore, attempt should be made now to provide a healthy environment to the next generations.

\subsection{Environmentalism, ad message credibility and green purchase intentions}

Environmentalism has emerged as an important topic in academic literature, social and political debates. Main-stream media played has also played a crucial role in spotlighting the environmental pollution and depletion of natural resources. The consistent focus on environmental issues has drawn the attention toward legislation and environmental policy making, production and consumption of green products and significant increase in companies' green advertising budgets [24]. These efforts played a significant role in creating environmental awareness, improving environmental consciousness and communicating green product's importance to conserve the natural environment. However, firms are facing the serious challenges in convincing the consumer to purchase the green products due to customers distrust toward credibility of advertisement messages and usefulness of the green products [25]. The main reasons of this scepticism are false claims, misleading and vague green marketing or advertising statements, fabricated or exaggerated impact of green products on environment [26]. Therefore, credibility and truthfulness of advertising messages play a key role in positively influencing the purchase behaviours of the customers.

\subsubsection{Environmentalism and ad message credibility}

Green marketing campaigns and green advertising have enormously contributed in educating the public and generating awareness about environmentalism. Many companies are 
doing genuine efforts, as their corporate social responsibilities, to produce and advertise green products to minimize their environmental impact [22, 23]. These attempts played an important role in increasing environment consciousness and convincing customers to consume green products [27]. Government and media around the world are playing an important role in generating environment awareness and convincing the people to consume environment-friendly products through public service messages. Similarly, government and environment protection authorities have pressurized the companies through legislation and environmental policies to produce and advertise green products and services to conserve the environment [28, 29]. The effectiveness of green advertising and message credibility depends on the environmental strategies designed to appeal to save environment [30]. Generally, people perceive advertisement messages only as compliance with these policies without the genuine contribution in minimizing their impact on the environment $[24,31]$. However, environmental conscious and alarmed consumers perceive these advertisement messages truthful and pay attention to them [25, 26]. Based on these theoretical backgrounds the following hypothesis is proposed;

H1: Environmentally conscious consumers positively perceive the credibility of green product's advertisement messages.

\subsubsection{Ad message credibility and green purchase intentions}

Consumers' perception of advertisement messages as believable and truthful depends on the credibility of the advertisement source $[32,33]$. People positively respond to the environmental claim if they believe that the source is honest and competent [34]. Generally, customers believe eco-friendly messages as misleading, vague, fabricated and substantiated without having any positive impact on environment [31]. Firms are facing a huge challenge to convince their environmentally knowledgeable customers to believe that their advertisement claims are trustworthy and genuinely contributing in conserving the environment [27]. Previous studies have confirmed that credible ad messages are very effective in catching the attention of environmentally concerned consumers and positively evaluate during their purchase decisions [35]. Similarly, ad message credibility provides effective input to green purchase decisions. Green products with believable promotional messages standout from competing products and are very successful in persuading consumers to prefer them during purchase decisions [30, 33]. Effective green messages facilitate consumers to elaborate their green product knowledge about green product's specifications and help them to support green purchasing to satisfy their environmental aspirations [36]. Credible advertisement messages stimulate customers to switch their purchase behaviours toward green products [37, 38]. Therefore, following hypothesis is proposed;

H2: Advertisement message credibility positively influences the green purchase intentions of the customers.

\subsection{Environmentalism, green perceived value and green purchase intentions}

Environmentally concerned consumers have been increasing tendency to evaluate the impact of products on environment before making the purchase decisions. This evaluation process includes the before (environmental input used to develop the product) and after (impact on environment due to usage and disposing off the product) effects of the products on environment [39]. Such consumers perceive higher value in environment concerning products and prefer them over competing products with protective feelings to contribute in conserving the environment. This perception of value, also known as ecological value and green value, is the influence by their green need, expectations and green satisfaction [13]. Many studies demonstrate that green value is a key factor in changing the consumption patterns of the environmentally conscious consumers [40]. Green value perception motivates consumers to buy those products having little harm to environment [41]. Therefore, products with green appeal trigger the green value perception and positively affect the consumers' purchase intentions.

\subsubsection{Environmentalism and green perceived value}

Customers' purchase decisions are mainly derived by their value perception about products and services. In fact, customer value perception is regarded as a decisive factor to evaluate product attractiveness. When the perception of value is motivated by environmental desires, green needs and sustainable expectations, then this value becomes the green perceived value $[13,42]$. Environmentally conscious consumers perceive high value in those products which are eco-friendly and impose less harm to environment. This value perception is reinforced by their feeling as an important part of society and urges to contribute in the wellbeing of the society [43]. Their positive attitude toward environment becomes the basis in perception of green value in products supporting environmental causes [44]. Therefore, consumers' perception of green value is directly attached with the awareness about the environmental issues [41]. Perception of higher utility value of green products enabling consumers to responsibly behave toward environment and at the same time forcing the firms to produce, label, and market proenvironmental products to meet the requirements of the green consumers [45]. Therefore, the consumption patterns of the consumers are largely influenced by the perception of values in environment friendly products with belief that their consumption ultimately affects the environment [46]. Following hypothesis is proposed on the basis of these considerations;

H3: Environmentalism positively influences the consumers' perception of values in the green products.

\subsubsection{Green perceived values and green purchase intentions}

Consumers compare green products with alternatives, similar to the conventional products, during their purchase decisions and prefer products high in green value. Perception of green value is defined as "an overall assessment of the net gain from a product or service between what is received and what is given based on the consumer's environmental desires, sustainable expectations, and green needs" [42]. This assessment positively contributes to the favourable response to the green products by enhancing green trust, relationship development and green satisfaction [46]. Green perceived value has gained a central position in the marketing strategies of the companies to positively influence the purchase intentions of the green consumers [44]. This also facilitates them to target new potential green market opportunities and to achieve the better market position through the effective commercialization of eco-friendly products. Previous studies found a positive link between perception of green values and 
green purchase intentions [47]. Customer with high-value perception had greater tendency to purchase the green products. Furthermore, green consumers tend to have positive product image and greater loyalty with green products [48] Companies that are successful in developing the green value in their products have witnessed higher green product sales and better financial performance [49]. Because, green consumers are ready to pay premium prices for green products to contribute to the environment sustainability and conservation $[39,50]$. Therefore, following hypothesis is proposed;

H4: Green perceived value positively influences the purchase intentions of the green products.

\subsection{Moderating effects of green product knowledge}

Individual knowledge about environmental concerns is termed as green knowledge [51] and people knowledge about environment-friendly products or green products is known as green product knowledge [52]. Consumers differentiate between conventional products and green products on the basis of eco-branding, eco-labelling, and environment-related advertisements. These marketing efforts enhance the consumer knowledge about the available green products [53]. Similarly, environmentally conscious consumer's quest for acquiring more knowledge about green products and apply this knowledge while making the purchase decisions [54]. These knowledgeable consumers positively respond to the green advertising and specific environment-related actions. They are convinced by the green advertising credibility and believe that adopting required actions ultimately contribute in minimizing the impact on the environment [55]. Their prior environmental knowledge encourages them to trust in message claim that all the environmental responsibilities and regulations are being met by the advertised green products [30]. In absence of green knowledge consumers' just perceive eco-friendly advertisement as a promtional tool without any direct envionrmental benefit. However, consumers' mind favourbly responds to the advertisement messages with green knolwedge. It means perception of ad message credibility varies with knowldge resides in mind of the consumer [56]. Such knowledge faciliates the consumers to recognize their ignorance, identify misinfomration and take ecofriendly purchase decisions based on ad message credibility. Consumers do not prefer green products in a buying situation without prior green knowledge. Because only the 'green' message of the products is not enough to make it into the consumers buying considerations [57].

Based on these considerations, it is concluded that green environment knowledge moderates the relationship between environmentalism and ad message credibility. Furthermore, consumers having more knowledge about environmental issues perceive more value and benefits of using green products [58]. Extensive environment knowledge motivates the consumers to be more responsible to environmental issues and behave in a more eco- friendly way aligned with their green perceived value [38]. Because, green knowledge helps them to believe that values offered by the green products exceed the values provided by the competing alternatives. In this way, green knowledge plays a value differentiation role to value the green products higher over the competing products during evaluation of alternatives [46]. Consumers tend to evaluate both emotional and functional benefits of green products on the basis of their prior environmental knowledge and perceive more value in products that strictly comply with environmental regulations [59]. On the basis of discussion, following hypotheses are proposed;

H5: Green product knowledge moderates the relationship between environmentalism and ad message credibility.

H6: Green product knowledge moderates the relationship of environmentalism and green perceived value in a significant manner.

All the above proposed structural relationships are presented in Figure 1.

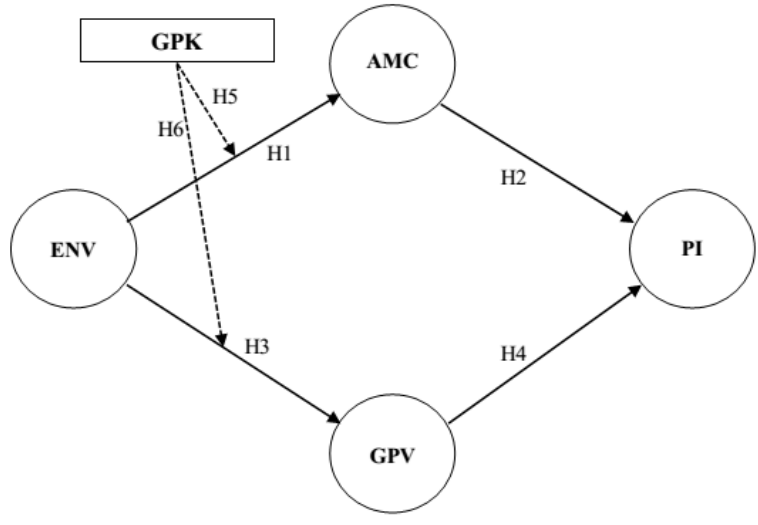

Moderating relationship

ENV: Environmentalism. AMC: Ad Message Credibility, GPV: Green Perceived Value, PI: Purchase Intensions, GPK: Green Product Knowledge

Figure 1. Conceptual model of the study

\section{RESEARCH METHODOLOGY}

\subsection{Research instrument}

Measurement scales used in this study were adapted from the previous related studies. All scales were analysed using a seven-point Likert Scale ranging from 1=Strongly Disagree to $7=$ Strongly Agree. Items used in this study are presented in Table 2. Environmentalism was measured by adapting the 10 items scale from Oliver and Rosen [50] with alpha 0.94. These items were adapted to measuring the importance environmental concerns among the respondents and their attitude toward these concerns. Advertisement Message Credibility was measured by adapting three items scale from Cotte, Coulter, and Moore, (2005) with alpha 0.87. These items were intended to measure respondents' perception about the credibility of advisement messages related to environmental issues. Green Perceived Value was measured by adapting eight items scale from Sangroya and Naya [13] with alpha 0.92 . These items were adapted to measuring the value perception of respondents about the eco-friendly products over the competing products. Green Purchase Intentions was measured by adapting three items scale from Sreen, Purbey, and Sadarangani [16] with alpha 0.85. These items were designed to measure the respondents' intentions to purchase the green products. The moderating variable Green Product Knowledge was measured by adapting two items scale from Liobikiene, Mandravickaite, and Bernatoniene [6] with alpha 0.86. These items were intended to measure the role of environmental knowledge in perception of credibility in advertisement messages and value in green products. 


\subsection{Data collection and analysis}

The self-administered questionnaire was distributed to respondents during personal interactions with the help of three enumerators who were graduate degree candidates. These enumerators were fully trained and briefed to conduct a survey. The participants were approached on the basis of convenience sampling technique with cross-sectional research design. The purpose and benefit of study was briefed to them, and questionnaires were only handed over to those respondents who were willing to participate in the study. Initially, the minimum sample size was determined by using the criteria of ten responses per item as recommended by Hair, Black, Babin, and Anderson [60]. However, the sample size was finalized by increasing the number of responses (fifteen per item) to increase the statistical power [61]. A total of 372 questionnaires were received. In data screening two questionnaires were excluded due to disengagement, and three were excluded due to incomplete responses. After data screening 367 valid questionnaires were used for further analysis. SPSS version 21.0 was used for coding, processing the descriptive statistics, reliability testing of data, internal consistency of the proposed constructs and to evaluate the demographic profile of the respondents (Table 1).

Table 1. Demographic profile of the respondents

\begin{tabular}{|c|c|c|c|c|c|}
\hline Category & $\mathbf{N}$ & \%age & Category & $\mathbf{N}$ & \%age \\
\hline \multicolumn{3}{|c|}{ Gender } & \multicolumn{3}{|c|}{ Area of Residence } \\
\hline Male & 173 & 47.1 & Rural & 129 & 35.1 \\
\hline Female & 194 & 52.9 & Urban & 238 & 64.9 \\
\hline $\begin{array}{l}20 \text { and } \\
\text { Below }\end{array}$ & 42 & 11.4 & \multicolumn{3}{|c|}{ Purchase Frequency (PF) } \\
\hline Age & & & \multirow{4}{*}{$\begin{array}{c}1-3 \text { times } \\
\text { 4-6 times } \\
\text { 6-10 times } \\
10-15 \\
\text { times }\end{array}$} & 148 & 40.3 \\
\hline $21-25$ & 105 & 28.6 & & 139 & 37.9 \\
\hline $26-30$ & 117 & 31.9 & & 68 & 18.5 \\
\hline $31-35$ & 76 & 20.7 & & 12 & 3.3 \\
\hline $\begin{array}{l}36 \text { and } \\
\text { Above }\end{array}$ & 27 & 7.4 & \multicolumn{3}{|c|}{ Monthly Spending (MS) } \\
\hline \multicolumn{3}{|c|}{ Qualification } & $\begin{array}{c}\text { Below } \\
1000\end{array}$ & 137 & 37.3 \\
\hline Matric & 11 & 3.0 & $\begin{array}{l}1000- \\
2000\end{array}$ & 169 & 46.0 \\
\hline Intermediate & 81 & 22.1 & $\begin{array}{l}2001- \\
3000\end{array}$ & 36 & 9.8 \\
\hline Under Grad & 144 & 39.2 & $\begin{array}{l}3001- \\
4000\end{array}$ & 16 & 4.4 \\
\hline Graduation & 108 & 29.4 & $\begin{array}{l}\text { Above } \\
4000\end{array}$ & 9 & 2.5 \\
\hline Mphil & 23 & 6.3 & \multicolumn{3}{|c|}{$\begin{array}{c}\text { Source of Motivation } \\
\text { (SM) }\end{array}$} \\
\hline \multicolumn{3}{|c|}{ Monthly Income } & Family & 82 & 22.3 \\
\hline $0-50000$ & 134 & 36.5 & Friend & 140 & 38.1 \\
\hline $\begin{array}{l}50001- \\
100000\end{array}$ & 167 & 45.5 & Neighbour & 105 & 28.6 \\
\hline $\begin{array}{l}100001- \\
150000\end{array}$ & 64 & 17.4 & Teacher & 39 & 10.6 \\
\hline $\begin{array}{l}150001- \\
200000\end{array}$ & 2 & .5 & Others & 1 & .3 \\
\hline
\end{tabular}

$\overline{P F}=$ Purchase frequency of green products per month, $M S=$ Monthly spend on purchasing the green products, SM= Source that motivated to purchase the green products

The conceptual model of the study was analysed by using Partial Least Square structural equation modelling analysis with Smart-PLS version 3.2.9 software. Two-stage analysis procedure recommended for SEM was used to analyse the measurement model (reliability and validity of measures) and to measure the structural model [62]. The conceptual model (Figure 1) was analysed by employing, PLS based SEM due to its strength in measuring path coefficients and modelling latent constructs following non-normality assumptions [62]. This technique is also becoming very popular for estimating models from marketing and management domains [63].

\section{FINDINGS AND RESULTS}

\subsection{Analysis of measurement model}

First of all, the convergent validity of the measurement model was assessed by measuring factor loadings. Composite Reliability (CR) and Average Variance Extracted (AVE) are presented in Table 2. Items having loadings less than recommended value of 0.6 were deleted from further analysis including two each from environmentalism and Green perceived value constructs. Table 2 shows that all the remaining items have loadings above the suggested value of 0.6 [64]. Composite Reliability values, which to the extent to which the construct indicators indicate the latent construct, ranged from 0.847 to 0.98 , also exceeded the recommended value of 0.7. Similarly, the Average Variance Extracted values, measures the variance captured by the indicators relative to measurement error, ranged from 0.649 to 0.923 , also exceeded the suggested value of 0.5 [62]. These values significantly support the evidences of convergent validity.

Table 2. Validity and reliability for constructs

\begin{tabular}{|c|c|c|c|c|}
\hline Constructs & Items & Loadings & AVE & CR \\
\hline \multirow{8}{*}{ 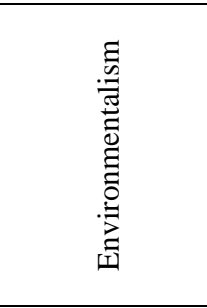 } & ENVLM1 & 0.867 & \multirow{8}{*}{0.702} & \multirow{8}{*}{0.949} \\
\hline & ENVLM2 & 0.88 & & \\
\hline & ENVLM3 & 0.872 & & \\
\hline & ENVLM4 & 0.805 & & \\
\hline & ENVLM5 & 0.817 & & \\
\hline & ENVLM6 & 0.893 & & \\
\hline & ENVLM7 & 0.809 & & \\
\hline & ENVLM & 0.749 & & \\
\hline \multirow{3}{*}{$\begin{array}{l}\text { Ad Message } \\
\text { Credibility }\end{array}$} & AMCR1 & 0.755 & \multirow{3}{*}{0.649} & \multirow{3}{*}{0.84} \\
\hline & AMCR2 & 0.815 & & \\
\hline & AMCR3 & 0.845 & & \\
\hline \multirow{6}{*}{$\begin{array}{c}\text { Green } \\
\text { Perceived } \\
\text { Value }\end{array}$} & GPVA1 & 0.711 & \multirow{6}{*}{0.693} & \multirow{6}{*}{0.931} \\
\hline & GPVA2 & 0.867 & & \\
\hline & GPVA3 & 0.877 & & \\
\hline & GPVA4 & 0.885 & & \\
\hline & GPVA5 & 0.871 & & \\
\hline & GPVA6 & 0.767 & & \\
\hline \multirow{3}{*}{$\begin{array}{l}\text { Green Purchase } \\
\text { Intention }\end{array}$} & GPIN1 & 0.961 & \multirow{3}{*}{0.923} & \multirow{3}{*}{0.98} \\
\hline & GPIN2 & 0.967 & & \\
\hline & GPIN3 & 0.962 & & \\
\hline \multirow{2}{*}{$\begin{array}{l}\text { Green Product } \\
\text { Knowledge }\end{array}$} & GPKN1 & 0.905 & \multirow{2}{*}{0.839} & \multirow{2}{*}{0.913} \\
\hline & GPKN2 & 0.927 & & \\
\hline
\end{tabular}

The subsequent step was to evaluate the discriminant validity, which depicts the degree to which the constructs differ or measure distinct concepts, reflected by presence of low correlations between the measure of interest and measure of other constructs. The discriminant validity is assessed by comparing the square root of AVE with the correlations and is supported when the square root of the AVE, presented in the diagonals, exceeds the values given in row and columns on that particular construct. From Table 3 , it can be noticed that values in diagonals exceeded the values given in the respective 
row and column. These values significantly support the evidence that measures are distinct, reflecting adequate discriminant validity [65]. A new method to check the discriminant validity is the Hetrotrait-Monotrait (HTMT) ratio of correlations based on Multitriat-Multimethod matrix [66]. The recommended criterion to establish the discriminant validity is the HTMT value less than 0.85 [67]. This method was also used to assess the discriminant validity. Table 4 shows the results of HTMT ratio of correlations and all the values are less than 0.85 . Therefore, discriminant validity is also established through this method.

Table 3. Discriminant validity

\begin{tabular}{cccccc}
\hline Constructs & $\mathbf{1}$ & $\mathbf{2}$ & $\mathbf{3}$ & $\mathbf{4}$ & $\mathbf{5}$ \\
\hline Ad Message Credibility & $\mathbf{0 . 8 0 6}$ & & & & \\
Environmentalism & 0.563 & $\mathbf{0 . 8 3 8}$ & & & \\
Green Perceived Value & 0.435 & 0.662 & $\mathbf{0 . 8 3 2}$ & & \\
Green Product Knowledge & 0.595 & 0.509 & 0.515 & $\mathbf{0 . 9 1 6}$ & \\
Purchase Intention & 0.355 & 0.453 & 0.516 & 0.498 & $\mathbf{0 . 9 6 1}$
\end{tabular}

Values on the diagonal (bolded) are square root of the AVE while the offdiagonals are correlations.

Table 4. Heterotrait-Monotrait Ratio (HTMT)

\begin{tabular}{cccccc}
\hline Constructs & $\mathbf{1}$ & $\mathbf{2}$ & $\mathbf{3}$ & $\mathbf{4}$ & $\mathbf{5}$ \\
\hline Ad Message Credibility & & & & & \\
Environmentalism & 0.678 & & & & \\
Green Perceived Value & 0.515 & 0.715 & & & \\
Green Product Knowledge & 0.755 & 0.583 & 0.593 & & \\
Purchase Intention & 0.409 & 0.474 & 0.544 & 0.56 & \\
\hline Shaded boxes are the standard reporting format for & HTMT procedure.
\end{tabular}

\subsection{Analysis of structural model}

The structural model was analysed by calculating the $\mathrm{R}^{2}$, beta and t-value of the hypothesized relationships by using bootstrapping method with a re-sample of 1000. In addition to these tests, the predictive relevance $\left(\mathrm{Q}^{2}\right)$ and the effect sizes $\left(\mathrm{f}^{2}\right)$ were also calculated as suggested by Hair et al. [62]. First of all, the structural relationship between the variables was analysed. Table 5 shows that environmentalism positively and significantly affected the ad message credibility $(\beta=0.570$; $\mathrm{P}<0.01)$ and the ad message credibility positively and significantly affected the green purchase intentions $(\beta=0.163$; $\mathrm{P}<0.05)$. Similarly, environmentalism positively and significantly affected the green perceived value $(\beta=0.662$; $\mathrm{P}<0.01)$ and green perceived value positively and significantly affected the green purchase intentions $(\beta=0.445 ; \mathrm{P}<0.01)$. These results supported the proposed hypotheses H1, H2, H3, and H4. Furthermore, the $\mathrm{R}^{2}$ values show that environmentalism explains $44.5 \%$ of variance in ad message credibility $\left(\mathrm{R}^{2}=0.445\right)$ and $43.8 \%$ of variance in green perceived value $\left(R^{2}=0.438\right)$, indicating a high $R$-square value. Similarly, ad message credibility and green perceived value explain $28.7 \%$ of variance in green purchase intentions, indicating a moderate $\mathrm{R}$-square value. These $\mathrm{R}^{2}$ values also support the above mentioned hypotheses as all values are above the recommended value of 0.26 [68].

In the next step, the effect size $\left(\mathrm{f}^{2}\right)$ was also calculated [62]. The Cohen's [68] guideline was used to assess the effect size that are 0.02 for small effects, 0.15 for moderate effects, and 0.35 for high effects. Table 5 shows that environmentalism, and green perceived value has highest effect sizes followed by environmentalism and ad message credibility whereas, all other relationships have been small to medium effect sizes. Further, the predictive relevance $\left(\mathrm{Q}^{2}\right)$ was calculated using blindfolding procedure [64]. The $\mathrm{Q}^{2}$ values greater than 0 means that proposed model has predictive relevance and $\mathrm{Q}^{2}$ value less than 0 means that model has no predictive relevance.

Table 5. Structural estimates (hypotheses testing)

\begin{tabular}{lccccc}
\hline & Hypotheses & Beta & T Value & f-Square & Decision \\
\hline H1: & Environmentalism $\rightarrow$ Ad Message Credibility & 0.570 & $14.882^{* *}$ & 0.48 & Supported \\
H2: & Ad Message Credibility $\rightarrow$ Purchase Intention & 0.163 & $3.316^{*}$ & 0.03 & Supported \\
H3: & Environmentalism $\rightarrow$ Green Perceived Value & 0.662 & $20.193^{* *}$ & 0.78 & Supported \\
H4: & Green Perceived Value $\rightarrow$ Purchase Intention & 0.445 & $9.379^{* *}$ & 0.23 & Supported \\
H5: & $\begin{array}{c}\text { Environmentalism } \times \text { Green Product Knowledge } \rightarrow \\
\text { Ad Message Credibility }\end{array}$ & 0.082 & $4.292^{* *}$ & 0.05 & Supported \\
H6: & Environmentalism $\times$ Green Product Knowledge $\rightarrow$ & \multirow{2}{*}{0.067} & $3.113^{*}$ & \multirow{2}{*}{0.04} & Supported \\
\hline
\end{tabular}
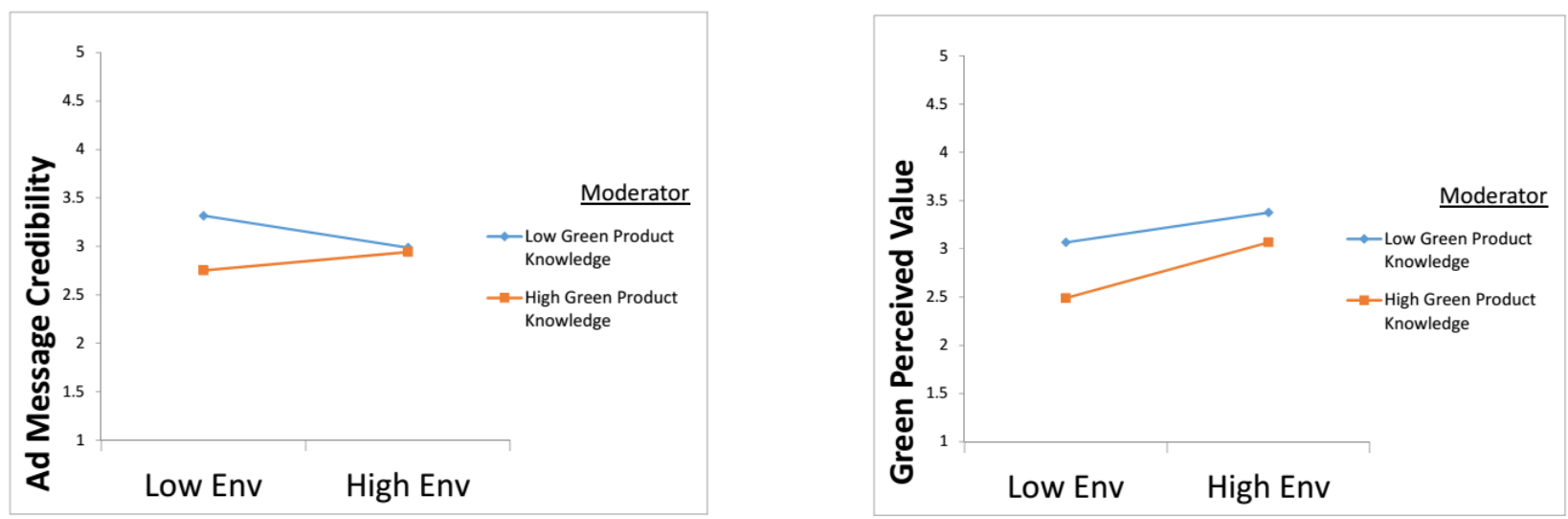

Figure 2. Moderation effects of green product knowledge 
Table 5 shows that $\mathrm{Q}^{2}$ value for all three endogenous variables is above 0 that support the presence of predictive relevance in the model. In addition, the mediation effects of ad message credibility and perceived value were also tested by using Preacher and Hayes method of bootstrapping the indirect effects [69]. The results indicate that the total indirect effect is significant $(\beta=0.31 ; \mathrm{P}<0.01 ; \mathrm{t}$-value=5.566). The results of specific indirect effects indicate that the ad message credibility does not mediate the relationship between environmentalism and green purchase intentions $(\beta=0.064 ; \mathrm{P}>0.05 ; \mathrm{t}$ value=1.916). However, green perceive value significantly mediate the relationship between environmentalism and green purchase intentions $(\beta=0.246 ; \mathrm{P}<0.01$; $\mathrm{t}$-value=5.62).

\subsection{Analysis of moderation}

In this study, it was hypothesized that Green product knowledge has a moderating effect on the relationships between environmentalism and ad message credibility and green purchase behaviour. These proposed moderating effects was analysed by using product-indicators approach. The presence of moderating effect was calculated by multiplying the environmentalism (predictor) and green product knowledge (moderator) to create an interaction construct (environmentalism $\times$ green product knowledge) to predict ad message credibility and green perceived value. Table 5 represents the estimated standardized path coefficients for the effect of moderator on ad message credibility $(\beta=0.082$; $\mathrm{P}<0.01)$ and green perceived value $(\beta=0.067 ; \mathrm{P}<0.05)$ were significant. These results indicate that green product knowledge significantly moderate the relationship between environmentalism, ad message credibility and green perceived value. Therefore, the proposed moderating hypotheses (H5 and H6) were also supported. The interaction effects were also plotted (Figure 2) to understand how the moderator, green product knowledge, changes the relationships between environmentalism, ad message credibility and green perceived value. Figure 2 shows that the relationship between environmentalism and ad message credibility is weaker when there is low green product knowledge and stronger when consumers have high green product knowledge. Furthermore, the relationship between environmentalism and green perceived value is stronger when consumers have high green product knowledge as compared to low green product knowledge.

\section{DISCUSSION}

This study validates the proposed multifactor conceptual model based on extensive literature review to analyse whether environmentalism contributes in changing the consumption patterns of the consumers and in the perception of credibility in environment-related advertisement messages and green value in the environment-friendly products. Furthermore, this study investigates the moderating role of green product knowledge by comparing two facets of product knowledge low and high, between the relationships of environmentalism, ad message credibility and green perceived value. Results presented in Table 5 shows that all the hypotheses are supported and aligned with the previous studies.

The hypothesis one shows that ad message credibility is strongly based on the environmental concerns of the consumers. Therefore, consumers favourably respond or not respond to the advertisement messages based on the message credibility derived from their approach towards environmental issues. If they believe that environmental issues are genuine and their efforts help to minimize the environmental impact, they surely respond favourably to the green advertisement messages [32]. Therefore, companies have to invest in creating environmental awareness campaigns and to convince the consumers that the green products are developed in compliance with all the requirements of environmental regularity authorities in pursuit of their goals to protect the environment [31].

Once, the consumers believe that advertisement claims are factual and honest they start paying attention and prefer to buy such products over the competing product [33]. Therefore, significant results of hypothesis-2 reinforce the findings of previous studies that firms need to establish credibility in persuasive communication of green products to positively change the consumption patterns of the consumers [36-38]. Results of Table 5 also significantly support the hypothesis-3 indicating that environmentally conscious consumers perceive high value in green products. Such consumers give high priority to products having more environmental benefits over the economic benefits with an urge to contribute in the betterment of environment [43].

Therefore, companies need to heavily invest in developing and improving the environmental conscientiousness among their consumers to increase the green value and ultimately improving the sales of green products [45]. Investing in environment awareness causes encourages consumers to think about their generations and to take remedial actions now to save them from devastating effects of worse environmental conditions in the future. Therefore, they fully support the environment-related activities and actively take actions to save environment. Such consumers consider green products as a valuable solution to save the environment and prefer to purchase them over the alternatives [44]. This is also supported by the significant results of hypothesis-4 strengthening the claim of previous studies that perception of green value is positively linked with the purchase intentions of the green products $[47,48]$. Results of mediation test indicate that the green perceive value significantly mediate the relationship between environmentalism and green purchase intentions. Hypothesis- 4 is also supported with fact that companies who have developed green value in their products overtime has high loyal customer's base and better financial performance $[39,49,50]$.

The moderation effects of green product knowledge also found advertisement message credibility and green perceived value, which result in more green purchase intentions. In other words, the environmentalism only increased ad message credibility, and green perceived value when a certain level of green product knowledge was present. When this green product knowledge was reached to certain level, the environmentalism's effects on ad message credibility and green perceive value were accelerated. This finding indicates that consumers having high green product knowledge were easily convinced by the persuasive green messages, as they found more credibility in such messages [55]. Similarly, consumers with high green product knowledge perceived more value in the green products during their purchase process to contribute in minimizing the environmental effects [38].

However, consumers having less green product knowledge were not easily convinced by the advertisement of green products as they had doubted in the credibility of advertised 
environmental claims. Such customers also perceived less value in the green products and had relatively less intention to purchase them. According to these findings, the green product knowledge needs to be enhanced to change the spending patterns of the consumer toward more environment friendly products and services. Therefore, when consumers with high green product knowledge are encountered with environmental advertisement claim their knowledge motivates them to pay attention, believes in claim and purchases green products to exercise their knowledge base [46]. This knowledge also triggers the value perception of green products and positively influences their green products' purchase intentions [58].

In this study, the green product knowledge played a significant role as a moderator. Therefore, resources must be invested in the awareness campaigns to raise the environmental consciousness and to enhance the green product knowledge to gain the credibility in products' green claims and perception of value to increase the purchase intentions of green products. Overall, findings of this study contributed in the existing literature by providing empirical support for environmentalism, ad message credibility, green perceived value and green product knowledge to the green purchase intentions.

\section{CONCLUSION}

The present study conceptualizes a multifactor model to understand the respondents approach toward environmental concerns and their efforts to minimize the environmental impact. This model successfully provides the comprehensive procedural approach to increase the purchase intentions of green products and to change the spending patterns to save the environment. Both structural paths, environmentalism-ad message credibility-green purchase intentions and environmentalism- green perceived value-green purchase intentions play a significant role in the green consumption behaviour. However, the second path has stronger effects as the perception of green value motivates consumers to prefer green products over the competing products during the purchase decisions. Green product knowledge, as a significant moderator, highlighted the importance of environmental knowledge enhancement through awareness campaigns to promote factual understanding of green knowledge. Marketers are required to promote products with sufficient information indicating green manufacturing, green usage and green disposal. Eco-labels are the valuable source to raise the value perception and to motivate the consumers to adopt green purchase behaviour. This is certainly possible by increasing the environmental realisation among consumers whom their consumption patterns are directly affecting the environment.

Therefore, they must opt the socially responsible behaviour and need to seriously consider the impact of their activities on the environment. Companies need to accumulatively invest in raising the environment consciousness and green product knowledge in general to increase the acceptance rate of their products in specific. The environmental consciousness will encourage companies to produce green products to remain competitive and to attract the green consumer segment. Similarly, it will facilitate the customers to pressurise the companies to adopt more environmental friendly procedures to produce and market their products. Therefore, governments, companies, marketers and consumers must have to play an active role to save the environment.
This study, like other studies, also have few limitations. First, this study considers green products in general for empirical support of conceptualised model. Different categories and variants of green products may produce different findings. Therefore, specific product categories should be considered in the future to further test this model. Second, advertisement message credibility may influence by many other factors like, culture, language, business ethics, source of communication. Therefore, these factors should be evaluated in the further studies to generalize the findings.

Third, Green perceived value is a situational phenomenon that is sensitive to change and can be influenced by many other factors. Perception of value may vary before purchase, during purchase and after purchase. Therefore, a longitudinal research design should be considered to trace the changes in the value perception due to situational changes. Fourth, the moderating effect of green product knowledge was tested on only two links. In future, the moderating effects of green product knowledge and additional moderators may be tested to explore the influence on the links of the proposed model.

\section{REFERENCES}

[1] White, P.C.L., Guégan, J.F., Keune, H., De Bell, S., Geijzendorffer, I.R., Hermans, T., Prieur-Richard, A.H., Iroegbu, C., Stone, D., Vanwambeke, S., de Vries, S., Ford, A., Graham, H. (2020). Integrative policy development for healthier people and ecosystems: A European case analysis. Area, 52(3): 495-504. https://doi.org/10.1111/area.12618

[2] Chi, Y., Zhang, Z., Xie, Z., Wang, J. (2020). How human activities influence the island ecosystem through damaging the natural ecosystem and supporting the social ecosystem? Journal of Cleaner Production, 248: 119203. https://doi.org/10.1016/j.jclepro.2019.119203

[3] Torkar, G., Bogner, F.X. (2019). Environmental values and environmental concern. Environmental Education Research, 25(10): 1570-1581. https://doi.org/10.1080/13504622.2019.1649367

[4] Fredriksson, P.G., Neumayer, E., Damania, R., Gates, S. (2005). Environmentalism, democracy, and pollution control. Journal of Environmental Economics and Management, $\quad$ 49(2): https://doi.org/10.1016/j.jeem.2004.04.004

[5] Akenji, L. (2014). Consumer scapegoatism and limits to green consumerism. Journal of Cleaner Production, 63: 13-23. https://doi.org/10.1016/j.jclepro.2013.05.022

[6] Liobikiene, G., Mandravickaite, J., Bernatoniene, J. (2016). Theory of planned behavior approach to understand the green purchasing behavior in the EU: A cross-cultural study. Ecological Economics, 125: 38-46. https://doi.org/10.1016/j.ecolecon.2016.02.008

[7] Chang, H.H., Tsai, S.H., Huang, C.C. (2019). Sustainable development: The effects of environmental policy disclosure in advertising. Business Strategy and the Environment, 28(8): 1497-1506. https://doi.org/10.1002/bse.2325

[8] Ritter, Á.M., Borchardt, M., Vaccaro, G.L.R., Pereira, G.M., Almeida, F. (2015). Motivations for promoting the consumption of green products in an emerging country: Exploring attitudes of Brazilian consumers. Journal of Cleaner Production, 106: 507-520. https://doi.org/10.1016/j.jclepro.2014.11.066 
[9] Lin, Y.C., Chang, C.C.A. (2012). Double standard: The role of environmental consciousness in green product usage. Journal of Marketing, 76(5): 125-134. https://doi.org/10.1509/jm.11.0264

[10] Tseng, S.C., Hung, S.W. (2013). A framework identifying the gaps between customers' expectations and their perceptions in green products. Journal of Cleaner Production, 59: 174-184. https://doi.org/10.1016/j.jclepro.2013.06.050

[11] Cotte, J., Coulter, R.A., Moore, M. (2005). Enhancing or disrupting guilt: The role of ad credibility and perceived manipulative intent. Journal of Business Research, 58(3): 361-368. https://doi.org/10.1016/S0148-2963(03)001024

[12] Wang, Y., Po Lo, H., Chi, R., Yang, Y. (2004). An integrated framework for customer value and customerrelationship-management performance: A customerbased perspective from China. Managing Service Quality: An International Journal, 14: 169-182. https://doi.org/10.1108/09604520410528590

[13] Sangroya, D., Nayak, J.K. (2017). Factors influencing buying behaviour of green energy consumer. Journal of Cleaner Production, 151: 393-405. https://doi.org/10.1016/j.jclepro.2017.03.010

[14] Osuide, S.O. (1990). Environmental pollution in Nigeria. Habitat International, 14(1): 5-15. https://doi.org/10.1016/0197-3975(90)90014-R

[15] Prothero, A. (1996). Environmental decision making: Research issues in the cosmetics and toiletries industry. Marketing Intelligence \& Planning, 14(2): 19-25. https://doi.org/10.1108/02634509610110769

[16] Sreen, N., Purbey, S., Sadarangani, P. (2018). Impact of culture, behavior and gender on green purchase intention. Journal of Retailing and Consumer Services, 41: 177-189. https://doi.org/10.1016/j.jretconser.2017.12.002

[17] Abas, A., Aziz, A., Tahir, Z., Othman, A.A., Payus, C.M. (2019). Understanding ecosystem services: A shift in modern environmentalism. International Journal of Advance and Applied Sciences, 6(12): 18-26. https://doi.org/10.21833/ijaas.2019.12.003

[18] Robinson, A.C., Downey, L.A., Ford, T.C., Lomas, J.E., Stough, C. (2019). Green teens: Investigating the role of emotional intelligence in adolescent environmentalism. Personality and Individual Differences, 138: 225-230. https://doi.org/10.1016/j.paid.2018.10.009

[19] Sen, A., Nagendra, H. (2019). The role of environmental placemaking in shaping contemporary environmentalism and understanding land change. Journal of Land Use Science, 14(4-6): 410-424. https://doi.org/10.1080/1747423X.2020.1720841

[20] Apergis, N., Garćia, C. (2019). Environmentalism in the EU-28 context: the impact of governance quality on environmental energy efficiency. Environmental Science and Pollution Research, 26: 37012-37025. https://doi.org/10.1007/s11356-019-06600-1

[21] Wolf-Watz, D., Sandell, K., Fredman, P. (2011). Environmentalism and tourism preferences: A study of outdoor recreationists in Sweden. Scandinavian Journal of Hospitality and Tourism, 11(2): 190-204. https://doi.org/10.1080/15022250.2011.583066

[22] Hjalager, A.M., Kwiatkowski, G. (2019). Relational environmentalism in coastal recreation and tourism. Sustainability, $\quad 11(21)$ : 6011 https://doi.org/10.3390/su11216011
[23] Hassan, A., Kouhy, R. (2015). From environmentalism to corporate environmental accountability in the Nigerian petroleum industry do green stakeholders matter? International Journal of Energy Sector Management, 9(2): 204-226. https://doi.org/10.1108/ijesm-05-2014-0008

[24] Royne, M.B., Martinez, J., Oakley, J., Fox, A.K. (2012). The effectiveness of benefit type and price endings in green advertising. Journal of Advertising, 41(4): 85-102. https://doi.org/10.1080/00913367.2012.10672459

[25] Liu, Y., Segev, S. (2017). Cultural orientations and environmental sustainability in households: A comparative analysis of Hispanics and non-Hispanic Whites in the United States. International Journal of Consumer Studies, 41(6): 587-596. https://doi.org/10.1111/ijcs.12370

[26] Fernando, A.G., Suganthi, L., Sivakumaran, B. (2014). If you blog, will they follow? Using online media to set the agenda for consumer concerns on "greenwashed" environmental claims. Journal of Advertising, 43(2): 167-180.

https://doi.org/10.1080/00913367.2013.841088

[27] Grillo, N., Tokarczyk, J., Hansen, E. (2008). Green advertising developments in the U.S. forest sector: A follow-up. Forest Products Journal, 58(5): 40-46.

[28] Zeng, H., Chen, X., Xiao, X., Zhou, Z. (2017). Institutional pressures, sustainable supply chain management, and circular economy capability: Empirical evidence from Chinese eco-industrial park firms. Journal of Cleaner Production, 155: 54-65. https://doi.org/10.1016/j.jclepro.2016.10.093

[29] Leonidou, L.C., Leonidou, C.N., Palihawadana, D., Hultman, M. (2011). Evaluating the green advertising practices of international firms: A trend analysis. Studies in Economics and Finance, 28(1): 6-33. https://doi.org/10.1108/02651331111107080

[30] Phau, I., Ong, D. (2007). An investigation of the effects of environmental claims in promotional messages for clothing brands. Marketing Intelligence and Planning, 25(7): 772-788. https://doi.org/10.1108/02634500710834214

[31] Segev, S., Fernandes, J., Hong, C. (2016). Is your product really green? A content analysis to reassess green advertising. Journal of Advertising, 45(1): 85-93. https://doi.org/10.1080/00913367.2015.1083918

[32] Rahim, M.H.A., Zukni, R.Z.J.A., Ahmad, F., Lyndon, N. (2012). Green advertising and environmentally responsible consumer behavior: The level of awareness and perception of Malaysian youth. Asian Social Science, 8(5): 46-54. https://doi.org/10.5539/ass.v8n5p46

[33] Barrage, L., Chyn, E., Hastings, J. (2020). Advertising and environmental stewardship: Evidence from the BP oil spill. American Economic Journal: Economic Policy, 12(1): 33-61. https://doi.org/10.1257/pol.20160555

[34] Schmuck, D., Matthes, J., Naderer, B., Beaufort, M. (2018). The effects of environmental brand attributes and nature imagery in green advertising. Environmental Communication, 12(3): https://doi.org/10.1080/17524032.2017.1308401

[35] Do Paço, A.M.F., Reis, R. (2012). Factors affecting skepticism toward green advertising. Journal of Advertising, 41(4): https://doi.org/10.1080/00913367.2012.10672463

[36] Sheehan, K., Atkinson, L. (2012). From the guest editors: Special issue on green advertising: Revisiting green 
advertising and the reluctant consumer. Journal of Advertising, 41(4): 5-7. https://doi.org/10.2307/23410029

[37] Vazifehdoust, H., Taleghani, M., Esmaeilpour, F., Nazari, K., Khadang, M. (2013). Purchasing green to become greener: Factors influence consumers' green purchasing behavior. Management Science Letters, 3: 2489-2500. https://doi.org/10.5267/j.msl.2013.08.013

[38] Sheng, G., Xie, F., Gong, S., Pan, H. (2019). The role of cultural values in green purchasing intention: Empirical evidence from Chinese consumers. International Journal of Consumer Studies, 43(3): 315-326. https://doi.org/10.1111/ijcs.12513

[39] Li, L., Long, X., Laubayeva, A., Cai, X., Zhu, B. (2020). Behavioral intention of environmentally friendly agricultural food: the role of policy, perceived value, subjective norm. Environmental Science and Pollution Research, 27: 18949-18961. https://doi.org/10.1007/s11356-020-08261-x

[40] Jiang, Y., Kim, Y. (2015). Developing multi-dimensional green value extending social exchange theory to explore customers' purchase intention in green hotels-evidence from Korea. International Journal of Contemporary Hospitality Management, 27(2): 308-334. https://doi.org/10.1108/IJCHM-08-2013-0383

[41] Biswas, A., Roy, M. (2015). Green products: An exploratory study on the consumer behaviour in emerging economies of the East. Journal of Cleaner Production, 87 : 463-468. https://doi.org/10.1016/j.jclepro.2014.09.075

[42] Chen, Y.S., Chang, C.H. (2012). Enhance green purchase intentions: The roles of green perceived value, green perceived risk, and green trust. Management Decision, 50(3):

$502-520$ https://doi.org/10.1108/00251741211216250

[43] Harahap, A., Zuhriyah, A., Rahmayanti, H., Nadiroh (2018). Relationship between knowledge of green product, social impact and perceived value with green purchase behavior. International Conference Series on Life Cycle Assessment: Life Cycle Assessment as a Metric to Achieve Sustainable Development Goals (ICSoLCA 2018), 74: 04002. https://doi.org/10.1051/e3sconf/20187404002

[44] Konuk, F.A. (2018). The role of store image, perceived quality, trust and perceived value in predicting consumers' purchase intentions towards organic private label food. Journal of Retailing and Consumer Services, 43: 304-310 https://doi.org/10.1016/j.jretconser.2018.04.011

[45] Kim, T., Yun, S. (2019). How will changes toward proenvironmental behavior play in customers' perceived value of environmental concerns at coffee shops? Sustainability, 11(14): 3816. https://doi.org/10.3390/su11143816

[46] Lin, J., Lobo, A., Leckie, C. (2017). The role of benefits and transparency in shaping consumers' green perceived value, self-brand connection and brand loyalty. Journal of Retailing and Consumer Services, 35: 133-141. https://doi.org/10.1016/j.jretconser.2016.12.011

[47] Lam, A.Y.C., Lau, M.M., Cheung, R. (2016). Modelling the relationship among green perceived value, green trust, satisfaction, and repurchase intention of green products. Contemporary Management Research, 12(1): 47-60. https://doi.org/10.7903/cmr.13842
[48] Confente, I., Scarpi, D., Russo, I. (2019). Marketing a new generation of bio-plastics products for a circular economy: The role of green self-identity, self-congruity, and perceived value. Journal of Business Research, 112: 431-439. https://doi.org/10.1016/j.jbusres.2019.10.030

[49] De Toni, D., Eberle, L., Larentis, F., Milan, G.S. (2018). Antecedents of perceived value and repurchase intention of organic food. Journal of Food Products Marketing, 24(4): https://doi.org/10.1080/10454446.2017.1314231

[50] Zulfanizy, K., Wahyono, W. (2019). The influence of green perceived value, risk and quality toward green purchase intention through green trust. Management Analysis Journal, 8: 79-89.

[51] Chan, R.Y.K., Lau, L.B.Y. (2002). Explaining green purchasing behavior: A cross-cultural study on American and Chinese consumers. Journal of International Consumer $\quad$ Marketing, 14(2-3): 9-40. https://doi.org/10.1300/J046v14n02_02

[52] Suki, M.N. (2016). Green product purchase intention: impact of green brands, attitude, and knowledge. British Food Journal, 118(12): 2893-2910. https://doi.org/10.1108/BFJ-06-2016-0295

[53] Rahbar, E., Wahid, N.A. (2011). Investigation of green marketing tools' effect on consumers' purchase behavior. Business Strategy Series, 12(2): 73-83. https://doi.org/10.1108/17515631111114877

[54] Kumar, P., Ghodeswar, B.M. (2015). Factors affecting consumers' green product purchase decisions. Marketing Intelligence and Planning, 33(3): 330-347. https://doi.org/10.1108/MIP-03-2014-0068

[55] Wang, Y., Li, Y., Zhang, J., Su, X. (2019). How impacting factors affect Chinese green purchasing behavior based on Fuzzy Cognitive Maps. Journal of Cleaner $\quad$ Production, 118199. https://doi.org/10.1016/j.jclepro.2019.118199

[56] Kim, S., Youn, S., Yoon, D. (2019). Consumers' responses to native vs. banner advertising: moderation of persuasion knowledge on interaction effects of ad type and placement type. International Journal of Advertising, 38(2): 207-236. https://doi.org/10.1080/02650487.2018.1451208

[57] Wheeler, M., Sharp, A., Nenycz-Thiel, M. (2013). The effect of "green" messages on brand purchase and brand rejection. Australasian Marketing Journal, 21(2): 105110. https://doi.org/10.1016/j.ausmj.2013.02.007

[58] Oliver, J., Rosen, D. (2010). Applying the environmental propensity framework: A segmented approach to hybrid electric vehicle marketing strategies. Journal of Marketing Theory and Practice, 18(4): 377-393. https://doi.org/10.2753/MTP1069-6679180405

[59] Leonidou, C.N., Skarmeas, D. (2017). Gray shades of green: Causes and consequences of green skepticism. Journal of Business Ethics, 144: 401-415. https://doi.org/10.1007/s10551-015-2829-4

[60] Hair, J.F., Black, W.C., Babin, B.J., Anderson, R.E. (2018). Multivariate Data Analysis. Pearson, Upper Saddle River New Jersey.

[61] Goodhue, D.L., Lewis, W., Thompson, R. (2012). Does PLS have advantages for small sample size or nonnormal data? MIS Quarterly, 36: 981-1001.

[62] Hair, J., Hult, G.T., Ringle, C., Sarstedt, M. (2017). A Primer on Partial Least Squares Structural Equation Modeling (PLS-SEM). Sage Publications, Los Angeles, 
CA.

[63] Ali, F., Kim, W.G., Ryu, K. (2016). The effect of physical environment on passenger delight and satisfaction: Moderating effect of national identity. Tourism Management, 57: 213-224. https://doi.org/10.1016/j.tourman.2016.06.004

[64] Chin, W.W., Peterson, R.A., Brown, S.P. (2008). Structural equation modeling in marketing: Some practical reminders. Journal of Marketing Theory and Practice, 16(4): 287-298. https://doi.org/10.2753/MTP1069-6679160402

[65] Fornell, C., Larcker, D.F. (1981). Evaluating structural equation models with unobservable variables and measurement error. Journal of Marketing Research, 18(1): 39-50. https://doi.org/10.2307/3151312
[66] Henseler, J., Ringle, C.M., Sarstedt, M. (2015). A new criterion for assessing discriminant validity in variancebased structural equation modeling. Journal of the Academy of Marketing Science, 43: 115-135. https://doi.org/10.1007/s11747-014-0403-8

[67] Kline, R.B. (2016). Principles and Practice of Structural Equation Modeling, 4th ed. The Guilford Press, New York.

[68] Cohen, J. (1988). Statistical Power Analysis for the Behavioral Sciences. Academic Press, New York.

[69] Preacher, K.J., Hayes, A.F. (2008). Asymptotic and resampling strategies for assessing and comparing indirect effects in multiple mediator models. Behavior Research Methods, 40: 879-891. https://doi.org/10.3758/BRM.40.3.879 